\title{
DEMOGRAFICZNE UWARUNKOWANIA ROZWOJU MIASTA POZNANIA
}

\section{WPROWADZENIE}

Podstawową charakterystyką określającą rozwój miast jest liczba zamieszkującej je ludności. Wiek XX oraz początki XXI stulecia dostarczaja w tym względzie zaskakujących statystyk. W 2007 r., pierwszy raz w historii, liczba ludności świata zamieszkującej w miastach przewyższyła liczbę mieszkańców wsi ${ }^{1}$. W roku 2014 ludność miejska stanowiła już ponad 54\%, podczas gdy w 1950 było to niespełna 30\% mieszkańców świata. Prognozy ONZ przewiduja, że w 2050 r. miasta zamieszkiwać będzie ponad 66\% ludności Ziemi. W Europie mieszkańcy miast już obecnie stanowią 73\% ludności kontynentu ${ }^{2}$. Według danych spisu ludności z 2011 r. ponad 60\% ludności Polski mieszka w miastach. Jednak ostatnie lata przyniosły w Polsce zmianę obserwowanej przez ponad 50 lat tendencji, tj. stopniowy wzrost udziału liczby ludności zamieszkującej na wsi.

W XX w. liczba mieszkańców największych polskich miast kilkukrotnie wzrosła. Trudne doświadczenia czasu wojny istotnie zakłóciły tę tendencję. Jednak intensywny proces powojennej urbanizacji i industrializacji sprzyjał dalszemu rozwojowi miast. Liczba mieszkańców Krakowa zwiększyła się ponad ośmiokrotnie, a Poznania pięciokrotnie ${ }^{3}$. Jednak od końca lat dziewięćdziesiątych obserwujemy nie tylko zmniejszanie się liczby mieszkańców największych miast, ale od poczattku XXI w. także przyrost liczby ludności wiejskiej na niekorzyść miast w skali całego kraju. Szczególnie dotkliwie zmiany te dotyczą Łodzi i Poznania, gdyż oznaczają spadek liczby mieszkańców w latach 1990-2013 o odpowiednio 137 tys. i 42 tys. Zjawisko to jest w dużej mierze spowodowane rozwojem ośrodków podmiejskich, procesem intensywnej suburbanizacji.

1 Problemy metodologiczne dotyczące pomiaru poziomu urbanizacji oraz zgodności wyników różnych szacunków są przedmiotem opracowania L. Alkema, G. W. Jones, C. U. R. Lai, Levels of Urbanization in the World's Countries: Testing Consistency of Estimates Based on National Definitions, „Journal of Population Research” 30, 2013, s. 291-304; UN, World Urbanization Prospects. Highlights. 2014 Rvision, United Nations, New York 2014, s. 7.

${ }^{2}$ Najbardziej zurbanizowanym regionem świata jest Ameryka Północna (82\% ludności mieszkającej w miastach), Ameryka Łacińska i Karaiby (80\%) (UN, World Urbanization Prospects...).

${ }^{3}$ W 1900 r. Kraków liczył 91 tys. mieszkańców, a 100 lat później już 759 tys. W przypadku Poznania przyrost ten był wolniejszy, od 117 tys. w roku 1900 do 582 tys. w 2000. 
Intensywność przemian demograficznych, niska dzietność, coraz dłuższe trwanie życia oraz bardzo liczne migracje, szczególnie młodych ludzi, powodują nie tylko natychmiastowe efekty, lecz także zmiany o długotrwałych konsekwencjach. Z tego powodu poznanie demograficznych uwarunkowań rozwoju miasta ma zasadnicze znaczenie w planowaniu strategicznym. Według opinii Johna Wilmoth, Dyrektora Population Division ONZ: „zarządzanie obszarami miejskimi stało się jednym z najważniejszych wyzwań rozwojowych w XXI w. Sukces lub niepowodzenie w tworzeniu zrównoważonych miast będzie głównym czynnikiem sukcesu agendy rozwoju ONZ po 2015 r."

Celem niniejszego opracowania jest przedstawienie przeszłych oraz przyszłych trendów rozwoju liczby mieszkańców miasta Poznania oraz wskazanie powiązań i relacji między rozwojem demograficznym miasta i otaczających je obszarów podmiejskich w zakresie starzenia się społeczeństwa, rynku pracy oraz poziomu wykształcenia. W trakcie badania poddano weryfikacji hipotezę, że proces starzenia się populacji mieszkańców centrum miasta jest bardziej zaawansowany aniżeli populacji mieszkającej na obszarach podmiejskich. Jednak sformułowano także przypuszczenie, że zmiany związane $\mathrm{z}$ procesem suburbanizacji prowadzą do zmniejszania się różnic oraz upodobniania się charakterystyk demograficznych ludności centrum miasta oraz jego najbliższego sassiedztwa. Podjęto próbę wskazania determinant tej sytuacji w intensywniejszym wydłużaniu trwania życia i wyraźniejszym obniżeniu płodności wśród mieszkańców strefy podmiejskiej. Przemiany procesów demograficznych starano się także powiązać ze zmianami społecznymi. Dłuższy okres edukacji skutkuje późniejszym rozpoczęciem kariery zawodowej, odroczeniem decyzji matrymonialnych i prokreacyjnych ${ }^{5}$. Wzrost poziomu wykształcenia wiąże się także z dłuższym okresem aktywności zawodowej, większym jej natężeniem, częstszym i szybszym powrotem do pracy po urodzeniu dziecka ${ }^{6}$. Zwrócono również uwagę na skutki zmian struktury wieku wynikające $\mathrm{z}$ migracji między miastem i jego otoczeniem. W miarę możności wynikających z dostępności odpowiednich informacji hipotezy te poddano weryfikacji empirycznej.

W rozważaniach uwzględniono ludność miasta Poznania oraz otaczającego je powiatu poznańskiego. Nie oznacza to ignorowania problemów funkcjono-

\footnotetext{
${ }^{4}$ „Managing urban areas has become one of the most important development challenges of the 21 st century. Our success or failure in building sustainable cities will be a major factor in the success of the post-2015 UN development agenda", John Wilmoth, Director of UN DESA's Population Division - tłumaczenie własne autorki (UN, World's Population Increasingly Urban with More than Half Living in Urban Areas, http://www.un.org/en/development/desa/news/population/ world-urbanization-prospects-2014.html (dostęp 10.07.2014).

${ }^{5}$ Por. W. Lutz et al., Demographic and Human Capital Trends in Eastern Europe and Sub-Saharan Africa, Migration Policy Institute, Washington, DC, 2008; I. E. Kotowska (red.), Strukturalne i kulturowe uwarunkowania aktywności zawodowej kobiet $w$ polsce, Scholar, Warszawa 2009.

${ }^{6}$ Por. A. Matysiak, Employment First, then Childbearing: Women's Strategy in Post-Socialist Poland, „Population Studies” 63, 2009, nr 3, s. 253-276; A. Rybińska, Motherhood after the Age of 35 in Poland, ,Studia Demograficzne” 2014, nr 1(165), s. 7-28.
} 
wania i zarządzania aglomeracją ani potrzeby właściwego jej definiowania. Zagadnienia te sa przedmiotem analiz m.in. Ośrodka Badań Metropolitarnych UAM i uzależniają zakwalifikowanie danego terytorium do aglomeracji miejskiej od spełnienia szeregu kryteriów ${ }^{7}$. Warto w tym miejscu wspomnieć o takich inicjatywach współpracy samorządowej, jak Stowarzyszenie Metropolia Poznań ${ }^{8}$. Uznajac, że kwestia delimitacji aglomeracji miasta Poznania wykracza poza ramy niniejszego opracowania, przyjęto ujęcie uwzględniające dostępność danych statystycznych, tj. miasta Poznania oraz 17 gmin położonych wokół miasta, które tworzą powiat poznański. Chociaż przedmiotem badania jest rozwój aglomeracji Poznania, dla celów porównawczych zamieszczono częste odwołania do sytuacji innych dużych miast polskich, a w szczególności aglomeracji Warszawy.

W pierwszej kolejności przedstawione zostaną zmiany liczby mieszkańców Poznania oraz obszarów podmiejskich z perspektywy faz rozwoju miasta według klasycznego, cyklicznego modelu urbanizacji L. van den Berga ${ }^{9}$. Następnie omówione zostaną struktury wieku obserwowane od początku XXI w., ze szczególnym uwzględnieniem okresu międzyspisowego. W dalszej kolejności wskazane zostaną zmiany struktury mieszkańców według pozostałych podstawowych charakterystyk demograficzno-społecznych. Modyfikacje struktury populacji omówione zostaną w powiązaniu z oceną natężenia podstawowych procesów demograficznych. Podjęta zostanie próba oceny i syntezy.

W badaniu wykorzystano dostępne informacje dotyczące rozwoju Poznania oraz największych polskich miast. Były to przede wszystkim wyniki narodowych spisów ludności przeprowadzonych w 2002 i w 2011 r., dane zawarte

${ }^{7}$ Przykładem innych opracowań zajmujących się tą problematyką są prace Komitetu Przestrzennego Zagospodarowania Kraju PAN pod redakcją T. Markowskiego i T. Marszała, Metropolie, obszary metropolitalne, metropolizacja. Problemy i pojęcia podstawowe, PAN, Komitet Przestrzennego Zagospodarowania Kraju, Warszawa 2006; P. Swianiewicza i U. Klimskiej, Spoteczne i polityczne zróżnicowanie aglomeracji $w$ Polsce. Waniliowe centrum, mozaika przedmieść, „Prace i Studia Geograficzne” 35, 2005, 45-70. Ciekawe rozwiązanie zagadnienia delimitacji na podstawie informacji o dojazdach do pracy proponuje H. Gruchociak, Delimitacja lokalnych rynków pracy $w$ Polsce $z$ wykorzystaniem modelowania wielopoziomowego, praca doktorska obroniona na Uniwersytecie Ekonomicznym w Poznaniu, 2013. Jeszcze inne podejście, z uwzględnieniem tzw. szerszej strefy miejskiej (Larger Urban Zone) stosowane jest w europejskim programie Urban Audit koordynowanym przez Eurostat (por. http://www.stat.gov.pl/gus/5840_13473_PLK_HTML. htm). Por. J. J. Parysek, Aglomeracje miejskie w Polsce oraz problemy ich funkcjonowania i rozwoju, w: idem, A. Tölle (red.), Wybrane problemy rozwoju i rewitalizacji miast: aspekty poznawcze i praktyczne, Biuletyn Instytutu Geografii Społeczno-Ekonomicznej i Gospodarki Przestrzennej Uniwersytetu im. Adama Mickiewicza w Poznaniu, Seria Rozwój Regionalny i Polityka Regionalna, WN UAM, Poznań 2008; T. Kaczmarek, U. Kaczmarek, R. Bul, Analiza relacji funkcjonalnych aglomeracji poznańskiej z otoczeniem regionalnym (w kontekście dyfuzyjno-absorpcyjnego modelu rozwoju), Instytut Geografii Społeczno-Ekonomicznej i Gospodarki Przestrzennej Centrum Badań Metropolitalnych Uniwersytet im. Adama Mickiewicza w Poznaniu, Poznań 2011.

8 Stowarzyszenie Metropolia Poznań jest stowarzyszeniem gmin i powiatów aglomeracji poznańskiej, do którego należa: Miasto Poznań, powiat poznański, gminy powiatu poznańskiego, Śrem, Szamotuły i Skoki, oraz gminy i powiaty wykazujące silne związki z aglomeracja poznańska.

${ }^{9}$ L. van den Berg et al., Urban Europe: A Study of Growth and Decline, Pergamon, Oxford 1982. 
w Rocznikach Demograficznych, Rocznikach Statystycznych Województw, Roczniku Statystycznym Poznania, Banku Danych Lokalnych GUS oraz w Bazie Danych Demografia GUS. Dla oceny przyszłych trendów odwołano się do wyników prognozy demograficznej GUS-u 2008-2035 ${ }^{10}$.

\section{STAN I STRUKTURA POPULACJI AGLOMERACJI POZNAŃSKIEJ Z PERSPEKTYWY FAZ ROZWOJU MIASTA}

Tylko w ostatnich jedenastu latach, od 2002 do 2013 r., liczba mieszkańców największych polskich miast uległa zmniejszeniu. W Łodzi zaobserwowano spadek liczby ludności o ponad 70 tys. (9,4\%; por. tab. 1). Ubywa również mieszkańców Poznania. Choć tempo spadku jest nieco wolniejsze, w ostatniej dekadzie liczba ludności miasta zmniejszyła się o blisko 30 tys. (5\%). Wyjątkiem wśród dużych miast w Polsce jest Warszawa, w której liczba mieszkańców wzrosła o 2,1\%. Perspektywy rozwoju miasta według prognozy GUS-u sugerują zmniejszanie liczby ludności Poznania o dalsze 60 tys. do 2035 r.

Zdecydowanie odmienne trendy zaobserwowano dla obszarów podmiejskich. Największy w wymiarze względnym wzrost liczby mieszkańców w bezpośrednim otoczeniu miasta dotyczy Poznania ${ }^{11}$. W ostatniej dekadzie liczba mieszkańców przedmieść zwiększyła się o ponad 80 tys. (31\%). Oczywiście w bezpośrednim otoczeniu Warszawy ${ }^{12}$ zaobserwowano znaczniejszy wzrost liczby mieszkańców, gdyż wyniósł on ponad 150 tys., jednakże w wymiarze względnym jest to niespełna 17\% (por. tab.1). Prognoza demograficzna wskazuje na dalszy wzrost liczby ludności obszarów podmiejskich w zbliżonym tempie.

Obserwowane zmiany liczby mieszkańców wpłynęły na modyfikację struktury ludności aglomeracji poznańskiej według miejsca zamieszkania. W liczącej w 2002 r. 845,3 tys. osób aglomeracji poznańskiej mieszkańcy miasta - centrum regionu stanowili 68\% (por. wykres 1). Dziesięć lat później, w 2013 r., w liczącej 886,8 tys. ludności aglomeracji udział mieszkańców powiatu poznańskiego zwiększył się o 7 punktów procentowych. Podobne zmiany zaobserwo-

${ }^{10}$ Dla 2035 r. wykorzystano prognozę GUS-u z 2008 r., gdyż nowsza prognoza opublikowana w 2014 r. nie obejmuje przekroju powiatów i miast na prawach powiatu. Szeroką dyskusję prognoz ludności dla Poznania i okolic w ujęciu jednostek administracyjnych przedstawia J. Paradysz, Prognoza demograficzna dla Poznania i powiatu poznańskiego do roku 2035, w: E. Gołata (red.), Migracje mieszkańców dużych miast, Zeszyty Naukowe Uniwersytetu Ekonomicznego w Poznaniu, Poznań 2012.

11 Por. T. Klimanek, Wyniki badania zachowań migracyjnych mieszkańców Poznania, w: E. Gołata (red.), op. cit.

12 Obszar podmiejski dla aglomeracji warszawskiej zdefiniowano, podobnie jak w przypadku Poznania, przyjmując kryterium bezpośredniego sąsiedztwa jednostek podziału administracyjnego. Przyjęto, że Funkcjonalny Obszar Miejski stanowi miasto oraz powiaty leżące w bezpośrednim sąsiedztwie miasta. W przypadku Warszawy uwzględniono powiaty: legionowski, miński, otwocki, piaseczyński, pruszkowski, warszawski zachodni, wołomiński. 
wać można w innych dużych miastach w Polsce. Charakteryzuje je jednak mniejsza intensywność. Przykładowo we wspomnianej dekadzie udział ludności zamieszkującej obszar podmiejski aglomeracji warszawskiej zwiększył się „zaledwie” o 3 punkty procentowe (por. wykres 2). Trzeba jednak mieć na uwadze fakt, że te 3 punkty procentowe to ponad 130 tys. osób.

Tabela 1

Liczba ludności Poznania i Warszawy w latach 2002-2035*

\begin{tabular}{|l|c|c|c|c|c|c|}
\hline \multirow{2}{*}{ Miasto } & \multicolumn{7}{|c|}{ Ludność } \\
\cline { 2 - 8 } & \multicolumn{2}{|c|}{ Centrum miasta } & \multicolumn{3}{c|}{ Obszar podmiejski } \\
\cline { 2 - 7 } & $\mathbf{2 0 0 2}$ & $\mathbf{2 0 1 3}$ & $\mathbf{2 0 3 5}$ & $\mathbf{2 0 0 2}$ & $\mathbf{2 0 1 3}$ & $\mathbf{2 0 3 5}$ \\
\hline Warszawa & 1688194 & 1724404 & 1880621 & 902102 & 1052874 & 1234298 \\
\hline Poznań & 577117 & 548028 & 489522 & 269380 & 352395 & 480014 \\
\hline $\begin{array}{l}\text { Różnica liczby } \\
\text { ludności (absolut- } \\
\text { na i względna) }\end{array}$ & $\mathbf{2 0 0 2 - 2 0 1 3}$ & $\mathbf{2 0 1 3 - 2 0 3 5}$ & $\mathbf{2 0 0 2 - 2 0 3 5}$ & $\mathbf{2 0 0 2 - 2 0 1 3}$ & $\mathbf{2 0 1 3 - 2 0 3 5}$ & $\mathbf{2 0 0 2 - 2 0 3 5}$ \\
\hline Warszawa & 36210 & 156217 & 192427 & 150772 & 181424 & 332196 \\
& $2,1 \%$ & $9,1 \%$ & $10,2 \%$ & $16,7 \%$ & $17,2 \%$ & $26,9 \%$ \\
\hline Poznań & -29089 & -58506 & -87595 & 83015 & 127619 & 210634 \\
& $-5 \%$ & $-10,7 \%$ & $-17,9 \%$ & $30,8 \%$ & $36,2 \%$ & $43,9 \%$ \\
\hline
\end{tabular}

* Dla 2035 r. wykorzystano prognozę GUS-u z 2008 r. (prognoza opublikowana w 2014 r. nie obejmuje powiatów i miast na prawach powiatu).

Źródło: Prognoza dla powiatów i miast na prawie powiatu oraz podregionów na lata 2011-2035; www. stat.gov.pl; Baza Demografia, GUS, http://demografia.stat.gov.pl/bazademografia/CustomSelectData. aspx?s=lud\&y=2011\&t=00/30/64 (dostęp: 10.07.2014).

Ukazanie dotychczasowych trendów rozwoju liczby ludności miasta oraz otaczającego go regionu umożliwia dyskusję na temat etapów rozwoju miasta z perspektywy zaproponowanego przez L. van den Berga ujęcia modelowego ${ }^{13}$. Konstrukcja ta bazuje na czterofazowym procesie rozwoju populacji miasta (core city) oraz otaczającego go regionu (fringe, suburbs, ring), które łącznie tworzą funkcjonalny obszar miejski (functional urban region-FUR ${ }^{14}$ ). W zależności od zgodności obserwowanych zmian wyróżnione fazy dzielą się na etapy

${ }^{13}$ L. van den Berg et al., op. cit.

${ }^{14}$ Podobnie jak w przypadku aglomeracji, kwestie delimitacji obszaru funkcjonalnego wykraczają poza przedmiot niniejszego opracowania. Zgodnie z przyjętą wcześniej koncepcją przyjęto definicję FUR dla Poznania, jako powiat miasto Poznań i powiat poznański. Dla porównania niektóre wskaźniki wyznaczono także dla podregionu poznańskiego. Wielość kryteriów wyodrębniania funkcjonalnego obszaru miejskiego oraz ogólność definicji powoduja, że poziom subiektywizmu przy określaniu jego zasięgu jest bardzo wysoki (por. K. Heffner, P. Gibas, Ośrodki wojewódzkie $i$ ich obszary funkcjonalne $w$ Polsce, Prezentacja na konferencji „Polityka miejska”, Uniwersytet Warszawski, 25.06.2013 r., http://www.euroreg.uw.edu.pl/media/prezentacje_konferencja_polityka_miejska/1.2._piotr_gibas_krystian_heffner_orodki_regionalne_i_ich_obszary_funkcjonalne_w_polsce.pdf). 


\section{Wykres 1}

Ludność miasta Poznania i powiatu poznańskiego w 2002 i 2013 r.

$\%$

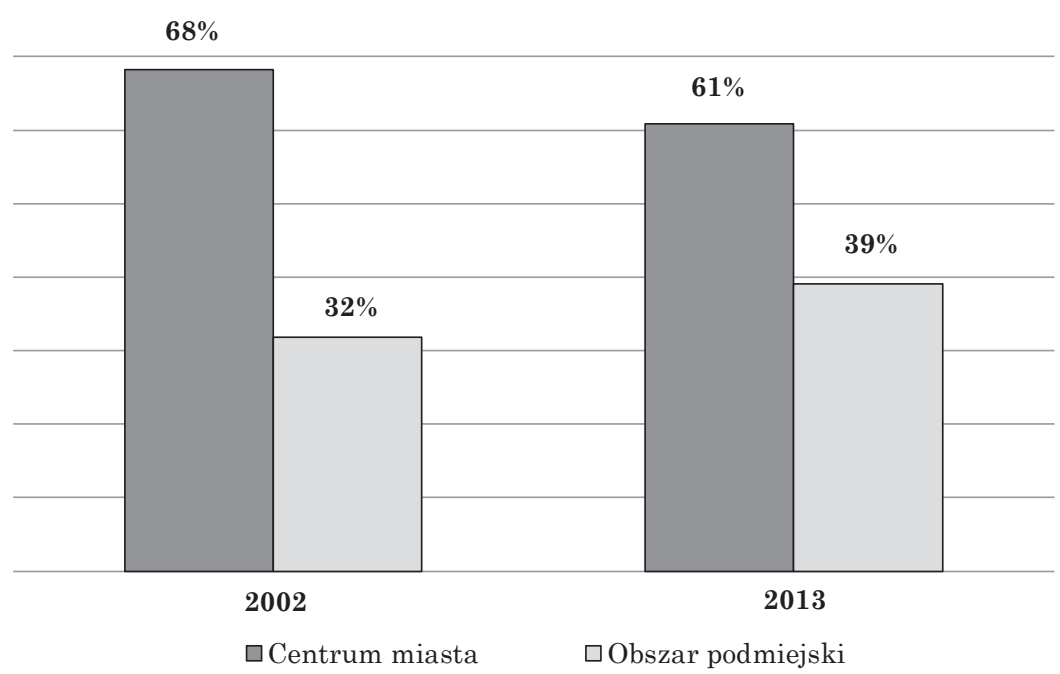

Źródło: Baza Demografia, GUS, http://demografia.stat.gov.pl/bazademografia/ (dostęp: 10.07.2014).

\section{Wykres 2}

Ludność Warszawy i obszaru metropolitalnego w 2002 i 2013 r.

$\%$

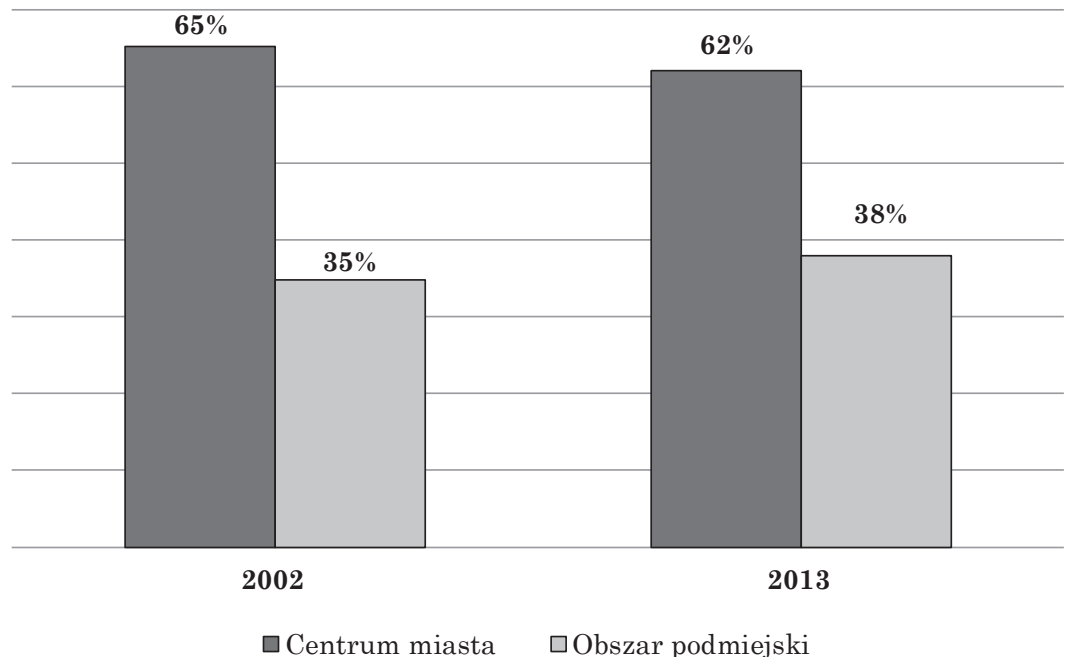

Źródło: Baza Demografia, GUS, http://demografia.stat.gov.pl/bazademografia/ (dostęp: 10.07.2014). 
określane jako absolutne przy przeciwnym kierunku (dywergencja) bądź względne, gdy obserwujemy jednokierunkowe zmiany różniące się natężeniem (konwergencja ${ }^{15}$ ).

Wyróżnione przez L. van den Berga et al. ${ }^{16}$ fazy cyklu rozwoju miasta to: urbanizacja, suburbanizacja, dezurbanizacja i reurbanizacja. U r b a n iz ację definiuje się jako wzrost liczby mieszkańców centrum miasta przy jednoczesnym zmniejszaniu się liczby mieszkańców obszarów podmiejskich (absolutna urbanizacja [1]). Bardzo szybko zaczyna rosnać również liczba mieszkańców przedmieść, jednak tempo wzrostu jest bardzo niewielkie. Etap ten określa się mianem względnej urbanizacji [2]. Początkowo powolne, a następnie coraz szybsze rozrastanie się obszarów podmiejskich oznacza przejście do fazy suburbanizacji. W szczególności gdy tempo wzrostu obszarów podmiejskich jest szybsze aniżeli centrum miasta (względna suburbanizacja [3]). Absolutną suburbanizację [4] obserwujemy, gdy liczba mieszkańców centrum miasta zaczyna się zmniejszać przy dalszym wzroście przedmieść. Faza dezurbanizacji oznacza absolutny spadek liczby mieszkańców całego funkcjonalnego obszaru miejskiego. Początkowo wzrost liczby ludności przedmieść jest mniejszy od spadku ludności centrum miasta (względna dezurbanizacja [5]). Następujące w kolejnym etapie jednoczesne zmniejszenie liczby mieszkańców obu obszarów oznacza proces absolutnej dezurbanizacji [6]. Kolejny etap cyklu rozwoju miasta pojawia się wówczas, gdy tempo spadku liczby mieszkańców centrum jest mniejsze aniżeli obserwowane na przedmieściach (względna reurbanizacja [7]). Cykl zamyka etap wzrostu liczby mieszkańców centrum - absolutna reurbanizacja (8). Jednakże etap reurbanizacji nie musi oznaczać wzrostu liczby mieszkańców całego obszaru funkcjonalnego (FUR). Powyższe cztery fazy rozwoju miasta w podziale na etapy względny i absolutny N. Kabisch i D. Haase ${ }^{17}$ porządkuja w formie zestawienia tabelarycznego (por. tab. 2).

Jeśli odniesiemy wyróżnione przez L. van den Berga et al. ${ }^{18}$ fazy cyklu rozwoju miasta do tendencji obserwowanych w Poznaniu, zauważymy przede wszystkim nieustanny spadek liczby mieszkańców centrum miasta przy jednoczesnym, stałym wzroście liczby mieszkańców powiatu i podregionu poznańskiego. W 2007 r. następuje zrównanie liczby mieszkańców miasta - centrum regionu oraz otaczającego je obszaru (por. wykres 3). Jednak tempo zmian ludnościowych w poszczególnych jednostkach terytorialnych jest zróżnicowane.

\footnotetext{
15 Por. P. Rérat, The New Demographic Growth of Cities: The Case of Reurbanisation in Switzerland, „Urban Studies” 49, 2012, nr 5 (April), s. 1107-1125.

${ }^{16}$ L. van den Berga et al., op. cit.

${ }_{17}$ N. Kabisch, D. Haase, Diversifying European Agglomerations: Evidence of Urban Population Trends for the 21st Century, „Population Space and Place” 17, 2011, s. 236-253.

18 L. van den Berg et al., op. cit.
} 
Tabela 2

Definicja faz rozwoju obszaru miejskiego

\begin{tabular}{|c|c|c|c|c|c|}
\hline \multirow[b]{2}{*}{ Faza rozwoju } & \multirow[b]{2}{*}{$\begin{array}{c}\text { Etap fazy } \\
\text { rozwoju }\end{array}$} & \multirow[b]{2}{*}{ Sekwencja } & \multicolumn{3}{|c|}{ Zmiana liczby ludności } \\
\hline & & & $\begin{array}{l}\text { Centrum } \\
\text { miasta }\end{array}$ & $\begin{array}{c}\text { Obszar } \\
\text { podmiejski }\end{array}$ & $\begin{array}{c}\text { Funkcjonalny } \\
\text { obszar } \\
\text { miejski }\end{array}$ \\
\hline \multirow[t]{2}{*}{ Urbanizacja } & Absolutna & 1. $\mathrm{AU}$ & ++ & - & + \\
\hline & Względna & 2. WU & ++ & + & +++ \\
\hline \multirow[t]{2}{*}{ Suburbanizacja } & Względna & 3. WS & + & ++ & +++ \\
\hline & Absolutna & 4. $\mathrm{AS}$ & - & ++ & + \\
\hline \multirow[t]{2}{*}{ Dezurbanizacja } & Absolutna & 5. $\mathrm{AD}$ & -- & + & - \\
\hline & Względna & 6. WD & -- & - & --- \\
\hline \multirow[t]{2}{*}{ Reurbanizacja } & Względna & 7. WR & - & -- & --- \\
\hline & Absolutna & 8. $\mathrm{AR}$ & + & -- & - \\
\hline
\end{tabular}

Uwagi:,,++++++ , oznacza wzrost liczby ludności, od powolnego $(+)$ do szybkiego $(+++)$ ,,------ , oznacza spadek liczby ludności, od powolnego $(-)$ do szybkiego $(---)$

Źródło: N. Kabisch, D. Haase, op. cit.

Dotyczy to nawet wartości przeciętnej od $1999^{19}$ r., która dla miasta Poznania wskazuje, że liczba mieszkańców rocznie maleje średnio o 0,45\%, podczas gdy w powiecie poznańskim obserwujemy przeciętny roczny wzrost o 2,29\%. Natomiast dla funkcjonalnego obszaru miejskiego traktowanego jako powiat miasto Poznań i poznański łącznie w latach 1999-2013 liczba mieszkańców rosła średnio o ok. 0,48\%. Pozwala to na identyfikację badanego okresu jako czasu absolutnej suburbanizacji, według faz rozwoju L. van den Berga.

Szczegółowa analiza dynamiki zmian liczby mieszkańców poszczególnych jednostek terytorialnych (por. wykres 4) pozwala zauważyć największe zróżnicowanie dla powiatu poznańskiego. W latach 1999-2004 przeciętnie z roku na rok liczba mieszkańców powiatu rosła o 1,81\%. W kolejnych sześciu latach (do 2010) tempo wzrostu zwiększyło się do 2,73\% rocznie. Lata 2010-2013 przynosza

19 Zmiana podziału administracyjnego kraju wprowadzajacca powiaty nastapiła od 1 stycznia 1999 r. Oczywiście możliwe są przeliczenia liczby ludności według „nowych” jednostek terytorialnych dla lat poprzednich. Jednak nawet te szacunki, które zostały udostępnione przez GUS, wymagają szczegółowej analizy, która wychodzi poza ramy niniejszego opracowania. 


\section{Wykres 3}

Liczba mieszkańców Poznania, powiatu i podregionu poznańskiego oraz funkcjonalnego obszaru miejskiego w latach 1999-2013

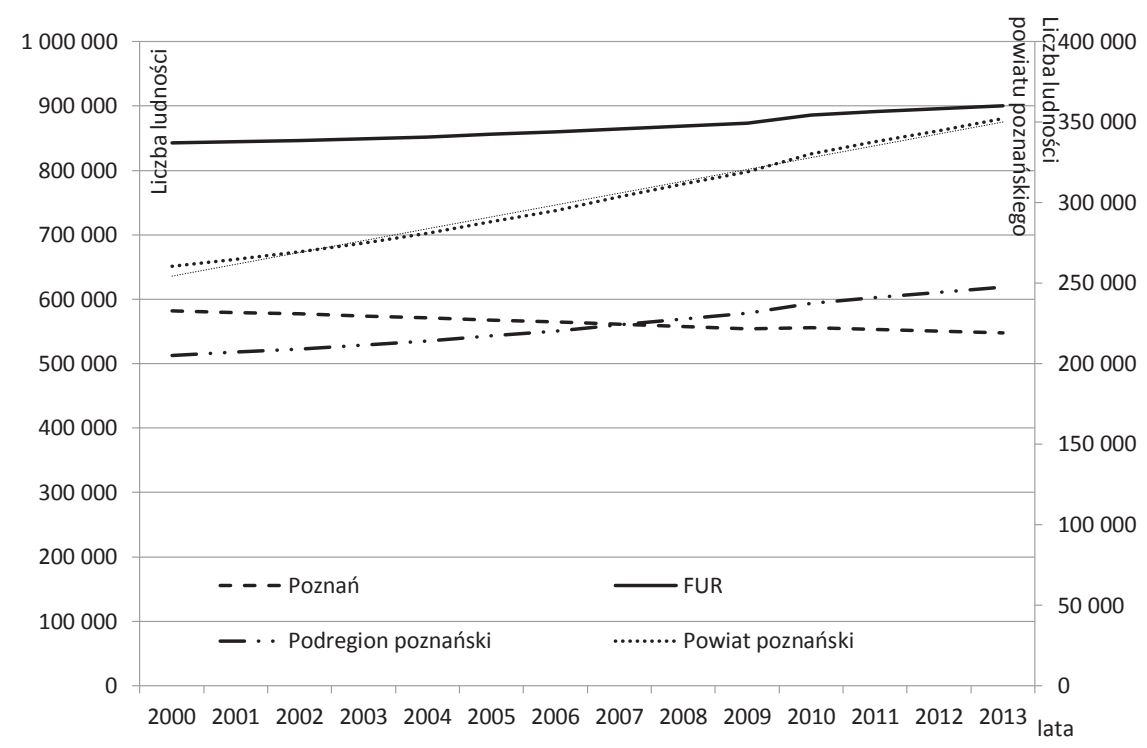

Źródło: Bank Danych Lokalnych, GUS.

\section{Wykres 4}

Dynamika zmian liczby mieszkańców Poznania, powiatu i podregionu poznańskiego oraz funkcjonalnego obszaru miejskiego w latach 1999-2013 (rok poprzedni = 1)

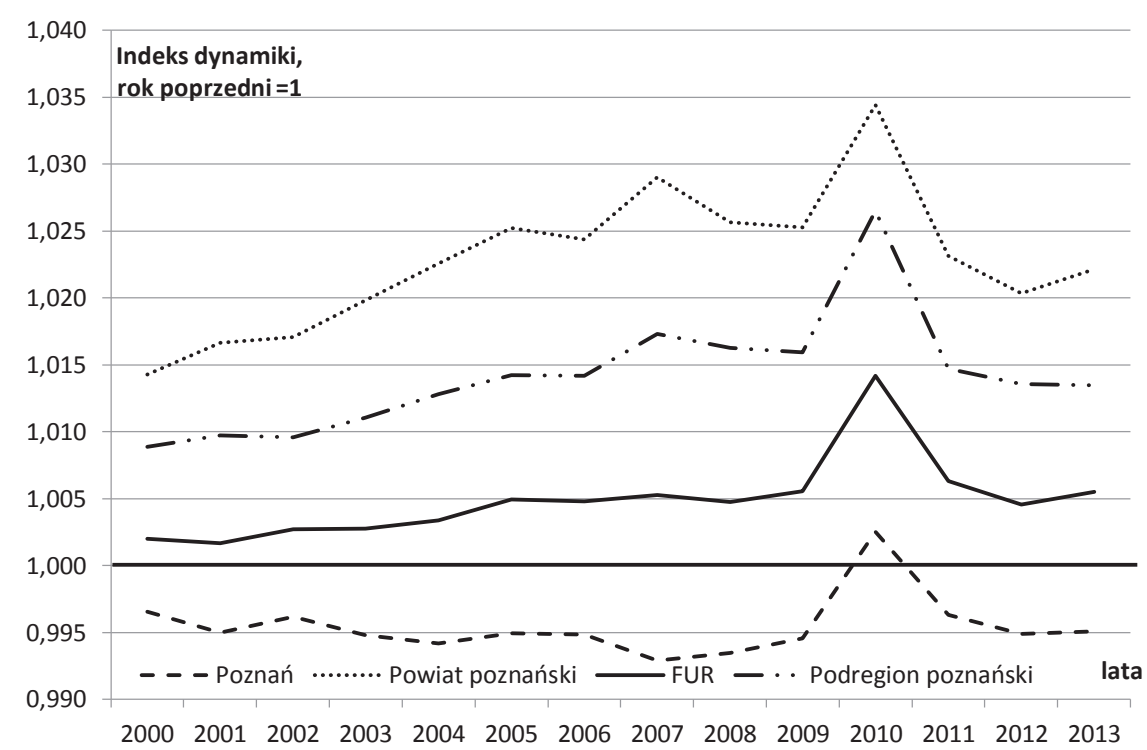

Źródło: Bank Danych Lokalnych, GUS. 
osłabienie przeciętnego rocznego tempa wzrostu liczby ludności powiatu poznańskiego do 2,19\%. Przeciętne tempo wzrostu liczby mieszkańców podregionu poznańskiego czy obszaru funkcjonalnego w podokresach (1999-2004, 2004-2010 oraz 2010-2013) charakteryzuja podobne zmiany wzrost i obniżenie: $1,0 \%-1,7 \%-1,4 \%$ (podregion) i $0,25 \%-0,66 \%-0,55 \%$ (FUR). Natomiast dla miasta - centrum regionu zmiany tempa spadku liczby mieszkańców sa mniej wyraźne. Obserwując słabnące tempo wzrostu liczby ludności obszaru funkcjonalnego, nieco wyraźniejsze w podregionie poznańskim, można przypuszczać, że zbliża się kolejna faza - absolutnej dezurbanizacji.

Tabela 3

Struktura wieku ludności* aglomeracji Poznania i Warszawy według miejsca zamieszkania w latach $2002-2035^{\text {*** }}$

\begin{tabular}{|l|c|c|c|c|c|c|}
\hline \multirow{2}{*}{ Wiek } & \multicolumn{7}{c|}{ Poznań } & \multicolumn{3}{c|}{ Warszawa } \\
\cline { 2 - 7 } & $\mathbf{2 0 0 2}$ & $\mathbf{2 0 1 3}$ & $\mathbf{2 0 3 5}$ & $\mathbf{2 0 0 2}$ & $\mathbf{2 0 1 3}$ & $\mathbf{2 0 3 5}$ \\
\hline \multicolumn{7}{|c|}{ Centrum miasta } \\
\hline 0-19 & 21 & 17 & 17 & 19 & 18 & 17 \\
\hline $20-69$ & 70 & 71 & 66 & 70 & 70 & 66 \\
\hline 70 i więcej & 9 & 11 & 17 & 11 & 13 & 17 \\
\hline 80 i więcej & 3 & 5 & 8 & 3 & 6 & 8 \\
\hline \multicolumn{7}{|c|}{ Obszar podmiejski } \\
\hline 0-19 & 28 & 24 & 20 & 26 & 23 & 20 \\
\hline $20-69$ & 65 & 69 & 67 & 66 & 68 & 65 \\
\hline 70 i więcej & 7 & 6 & 13 & 8 & 9 & 15 \\
\hline 80 i więcej & 2 & 2 & 5 & 2 & 3 & 6 \\
\hline
\end{tabular}

* Odsetek ludności danej grupy wieku.

** Dla 2035 r. wykorzystano prognozę GUS-u z 2008 r. (prognoza opublikowana w 2014 r. nie obejmuje powiatów i miast na prawach powiatu).

Źródło: Prognoza dla powiatów i miast na prawie powiatu oraz podregionów na lata 2011-2035; www. stat.gov.pl; Baza Demografia, GUS, http://demografia.stat.gov.pl/bazademografia/CustomSelectData. aspx?s=lud\&y=2011\&t=00/30/64 (dostęp: 10.07.2014).

Przedstawiając zmiany liczby mieszkańców miasta oraz otaczającego je regionu z perspektywy teorii cyklicznego rozwoju, warto zwrócić uwagę także na jej krytykę ${ }^{20}$. Wśród podnoszonych kwestii dyskusyjnych wskazać można na wielość sposobów delimitacji miasta, przedmieść oraz funkcjonalnego obszaru miejskiego, modelowe ujęcie negatywnych konsekwencji takich uwarunkowań zmian, jak wysokie ceny mieszkań w centrum czy koszty transportu i komunikacji na przedmieściach. Modelowa cykliczność rozwoju miast sugeruje też,

${ }^{20}$ Por. P. Rérat, op. cit. 
że proces reurbanizacji jest związany z kurczeniem się przedmieść. P. Rérat ${ }^{21}$ zwraca uwagę na fakt, że bazujace na liczbie ludności wskaźniki brane pod uwage w ocenie faz rozwoju miasta nie uwzględniają społeczno-demograficznej charakterystyki uwarunkowań jego rozwoju. Autor nie wskazuje bezpośrednio na rolę czynników demograficznych oraz nie bada wpływu zmian struktury wieku na intensywność procesów ludnościowych. W dalszej części rozważań podjęto próbę analizy konsekwencji przemian demograficznych z perspektywy rozwoju miasta.

Ludność zamieszkująca obszary podmiejskie jest wyraźnie młodsza aniżeli mieszkająca w centrum Poznania. Jednak dla obydwu typów obszarów w latach 2001-2013 obserwujemy bardzo intensywny proces starzenia. W szczególności zauważyć należy zmniejszenie udziału ludzi młodych, w wieku do 19 lat z 21\% do 17\% w Poznaniu oraz z 28\% do 24\% w powiecie poznańskim (por. tab. 3). W Warszawie spadek udziału dzieci i młodzieży w wieku do 19 lat był jednoprocentowy. Tak więc stolica starzeje się zdecydowanie wolniej, również w porównaniu z innymi obszarami. W przypadku obszarów podmiejskich otaczających Warszawę spadek udziału ludności w wieku do 19 lat wyniósł 3\%. Spadek udziału ludności najmłodszych grup wieku rekompensuje wzrost udziału ludności starszej, w wieku 70 lat i więcej (o $2 \%$ ) oraz najstarszej w wieku 80 i więcej lat (2\%). Podobny wzrost zaobserwowano w Warszawie. Jednakże wzrost odsetka ludności starszej i najstarszej nie jest obserwowany w powiecie poznańskim, gdzie zanotowano nawet spadek udziału ludności w wieku powyżej 70 lat z 7\% do 6\%. Na obszarach podmiejskich Warszawy o jeden procent zwiększył się udział ludności w wieku powyżej 70 lat.

\section{DEMOGRAFICZNE UWARUNKOWANIA STARZENIA SIĘ POPULACJI AGLOMERACJI POZNAŃSKIEJ}

Proces starzenia się uwarunkowany jest zmianami w zakresie płodności oraz trwania życia, co określane jest mianem starzenia się od podstaw oraz od wierzchołka piramidy wieku ${ }^{22}$. Pierwsze ujęcie dotyczy zmian w zakresie płodności. Zauważamy przede wszystkim, że w analizowanym czasie współczynnik dzietności ${ }^{23} \mathrm{w}$ Polsce zwiększył się, i to w każdym z analizowanych przekrojów terytorialnych, z wyjątkiem wsi (por. tab. 4). W ujęciu całego kraju wzrost ten wydaje się stosunkowo niewielki (0,6\%). Jednak uwzględnienie miejsca zamieszkania wprowadza bardzo znaczne zróżnicowanie. W miastach dzietność kobiet wzrosła o 6\%, w dużych miastach liczących powyżej 100 tys. mieszkańców - nawet o $12 \%$, a w największych - o ponad $20 \%$. W Warszawie

\footnotetext{
21 Por. ibidem.

22 Określenie „piramida wieku” to nazwa wykresu stosowanego w demografii dla ukazania struktury ludności według dwóch podstawowych cechy demograficznych, tj. płci i wieku.

${ }^{23}$ Współczynnik dzietności teoretycznej to syntetyczna miara natężenia płodności. Wskazuje on przeciętną liczbę dzieci urodzonych przez kobietę w całym okresie prokreacyjnym, przy założeniu takiego natężenia urodzeń według wieku, jakie zaobserwowano w badanym roku.
} 
współczynnik dzietności wzrósł o 27\%, a w Poznaniu o 21\%. Natomiast na wsi natężenie płodności kobiet zmniejszyło się nawet o $20 \%$.

Te „optymistyczne” spostrzeżenia należy jednak skorygować, wskazując poziom współczynnika o blisko połowę niższy od zapewniającego reprodukcje prostą ${ }^{24}$ oraz obserwowane zwiększenie natężenia „odłożonych w czasie” urodzeń przez kobiety z roczników wyżu demograficznego początku lat osiemdziesiątych ubiegłego stulecia ${ }^{25}$. W tym miejscu warto także zwrócić uwagę na zmiany społeczne podkreślone przez odmienny kierunek dynamiki natężenia płodności kobiet miejskich i wiejskich. Obserwowanemu 6-procentowemu wzrostowi natężenia urodzeń w miastach towarzyszył blisko 8-procentowy spadek dzietności na wsi. Dotyczy to wykraczającego poza ramy niniejszego opracowania problemu - zmian struktury płci ludności wiejskiej szczególnie w wieku najbardziej mobilnym, migracji, edukacji, niedopasowania na tzw. rynku matrymonialnym.

Zdecydowanie odmienny jest charakter wsi położonych w pobliżu dużych miast, które łącznie z miasteczkami i osiedlami tworzą funkcjonalny obszar miejski. Zarówno w 2002, jak i w 2013 r. natężenie płodności na obszarach wokół Poznania było istotnie wyższe aniżeli w mieście. Współczynnik dzietności kobiet mieszkajacych w powiecie poznańskim był w 2002 r. o ponad 20\% wyższy aniżeli dla mieszkanek Poznania. W 2013 r. różnica między dzietnością poznanianek oraz mieszkanek powiatu była mniejsza, ale nadal wynosiła blisko 17\%. Podobną relację zaobserwowano również w innych aglomeracjach, także warszawskiej (por. tab. 4). Pomimo zmniejszania się różnic w poziomie dzietności w Poznaniu oraz najbliższym otoczeniu miasta, obserwowana rozbieżność jest istotnym czynnikiem określajaccym tempo procesu starzenia się obu populacji.

Starzenie od wierzchołka piramidy związane jest z ogólną poprawą warunków życia, wzrostem higieny, postępem medycyny, promocją tzw. zdrowego stylu życia. Polska należy do państw, w których wzrost trwania życia obserwowany w ostatnich latach był szczególnie intensywny ${ }^{26}$. Tylko od 1995 r. oczekiwane dalsze trwanie życia mężczyzn wzrosło o 5,5 roku, a kobiet o 4,7 roku (por. tab. 5). Tendencja ta jest nadal równie intensywna. Tylko ostatnia dekada (2002-2013) przyniosła wydłużenie trwania życia dla mężczyzn o 2,7 roku i o 2,3 roku dla kobiet.

\footnotetext{
${ }^{24}$ Więcej informacji na temat zmian w zakresie reprodukcji, formowania się rodziny oraz płodności określanych mianem przejścia czy drugiego przejścia demograficznego znaleźć można w opracowaniach: D. J. van de Kaa, Europe’s Second Demographic Transition, „Population Bulletin" 42, 1987, nr 1, s. 1-59; H.-P. Kohler, F. C. Billari, J. A. Ortega, The Emergence of Lowest-Low Fertility in Europe during the 1990s, „Population and Development Review” 28, 2002, nr 4, s. 641680; czy H.-P. Kohler, J. A. Ortega, Tempo-Adjusted Period Parity Progression Measures, Fertility Postponement and Completed Cohort Fertility, „Demographic Research” 6, 2002, nr 6, s. 91-144.

${ }_{25}$ Por. T. Sobotka, Is Lowest-Low Fertility in Europe Explained by the Postponement of Childbearing?, „Population and Development Review” 30, 2004, nr 2, s. 195-220; A Rybińska, op. cit., s. 7-28; A. Matysiak, op. cit.

${ }^{26}$ Od 1950 r. przeciętne trwanie życia w Polsce wzrosło o ponad 16 lat dla mężczyzn (z 56,1 do 72,2 ) oraz o blisko 20 lat dla kobiet (z 61,7 do 81). Przy czym 40\% przyrostu obserwowanego dla mężczyzn i 30\% dla kobiet nastapiło w ostatnich 20 latach (od 1990 r.). Znaczne wydłużenie trwania życia dotyczy ludności w wieku starszym, 60 i więcej lat (Por. W. C. Sanderson, S. Scherbov, Rethinking Age and Ageing, „Population Bulletin” 63, 2008, nr 4, December).
} 


\section{Tabela 4}

Współczynnik dzietności teoretycznej w aglomeracji Poznania i Warszawy na tle kraju w latach 2002-2013

\begin{tabular}{|c|c|c|c|c|}
\hline \multirow{2}{*}{ Wyszczególnienie } & \multicolumn{4}{|c|}{$\begin{array}{l}\text { Współczynnik dzietności teoretycznej } \\
\text { według miejsca zamieszkania }\end{array}$} \\
\hline & \multicolumn{2}{|c|}{2002} & \multicolumn{2}{|c|}{2013} \\
\hline Polska & \multicolumn{2}{|c|}{1,249} & \multicolumn{2}{|c|}{1,256} \\
\hline Miasta & \multicolumn{2}{|c|}{1,110} & \multicolumn{2}{|c|}{1,176} \\
\hline $\begin{array}{l}\text { Miasta liczące } 100 \text { tys. } \\
\text { mieszkańców i więcej }\end{array}$ & \multicolumn{2}{|c|}{1,022} & \multicolumn{2}{|c|}{1,147} \\
\hline \multirow[t]{2}{*}{ Wsie } & \multicolumn{2}{|c|}{1,488} & \multicolumn{2}{|c|}{1,370} \\
\hline & $\begin{array}{c}\text { Centrum } \\
\text { miasta }\end{array}$ & $\begin{array}{c}\text { Obszar } \\
\text { podmiejski }\end{array}$ & $\begin{array}{c}\text { Centrum } \\
\text { miasta }\end{array}$ & $\begin{array}{c}\text { Obszar } \\
\text { podmiejski }\end{array}$ \\
\hline Warszawa & 0,958 & 1,172 & 1,214 & 1,366 \\
\hline Poznań & 0,967 & 1,212 & 1,167 & 1,403 \\
\hline
\end{tabular}

Źródło: Baza Demografia, GUS, http://demografia.stat.gov.pl/bazademografia/CustomSelectData.aspx?s $=$ lud\&y=2011\&t=00/30/64 (dostęp: 10.07.2014).

Tabela 5

Oczekiwane dalsze trwanie życia według płci i wieku

- mieszkańcy aglomeracji Poznania i Warszawy na tle kraju w latach 2002-2013

\begin{tabular}{|c|c|c|c|c|c|c|c|c|}
\hline \multirow{3}{*}{ Wyszczególnienie } & \multicolumn{8}{|c|}{$\begin{array}{l}\text { Oczekiwane dalsze trwanie życia według płci, } \\
\text { wieku i miejsca zamieszkania }\end{array}$} \\
\hline & \multicolumn{4}{|c|}{ Mężczyźni } & \multicolumn{4}{|c|}{ Kobiety } \\
\hline & \multicolumn{2}{|c|}{$\mathbf{e}_{0}$} & \multicolumn{2}{|c|}{$\mathbf{e}_{60}$} & \multicolumn{2}{|c|}{$\mathbf{e}_{0}$} & \multicolumn{2}{|c|}{$\mathbf{e}_{60}$} \\
\hline 1995 & \multicolumn{2}{|c|}{67,6} & \multicolumn{2}{|c|}{15,8} & \multicolumn{2}{|c|}{76,4} & \multicolumn{2}{|c|}{20,5} \\
\hline 2002 & \multicolumn{2}{|c|}{70,4} & \multicolumn{2}{|c|}{17,2} & \multicolumn{2}{|c|}{78,8} & \multicolumn{2}{|c|}{22,2} \\
\hline Miasta & \multicolumn{2}{|c|}{70,7} & \multicolumn{2}{|c|}{17,3} & \multicolumn{2}{|c|}{78,6} & \multicolumn{2}{|c|}{22,0} \\
\hline \multirow[t]{4}{*}{ Wsie } & & & & & & & & \\
\hline & \multicolumn{4}{|c|}{ Centrum miasta } & \multicolumn{4}{|c|}{ Obszar podmiejski (NTS3)* } \\
\hline & \multicolumn{2}{|c|}{ Mężczyźni } & \multicolumn{2}{|c|}{ Kobiety } & \multicolumn{2}{|c|}{ Mężczyźni } & \multicolumn{2}{|c|}{ Kobiety } \\
\hline & $\mathbf{e}_{0}$ & $\mathbf{e}_{60}$ & $\mathbf{e}_{0}$ & $\mathbf{e}_{60}$ & $\mathbf{e}_{0}$ & $\mathbf{e}_{60}$ & $\mathbf{e}_{0}$ & $\mathbf{e}_{60}$ \\
\hline Warszawa & 74,7 & 20,3 & 81,0 & 24,0 & 69,2 & 16,6 & 78,0 & 21,6 \\
\hline \multirow[t]{3}{*}{ Poznań } & 72,0 & 17,8 & 78,7 & 22,1 & 70,5 & 16,7 & 78,5 & 21,8 \\
\hline & \multicolumn{4}{|c|}{ Mężczyźni } & \multicolumn{4}{|c|}{ Kobiety } \\
\hline & \multicolumn{2}{|c|}{$\mathbf{e}_{0}$} & \multicolumn{2}{|c|}{$\mathbf{e}_{60}$} & \multicolumn{2}{|c|}{$\mathbf{e}_{0}$} & \multicolumn{2}{|c|}{$\mathbf{e}_{60}$} \\
\hline 2013 & & & & & & & & \\
\hline Miasta & & & & & & & & \\
\hline Wsie & & & & & & & & \\
\hline & & Centru & miast & & Ob: & $r$ podr & jjki ( & S3)* \\
\hline & Mę̇ & yźni & Ko & ety & Mę & yźni & & ety \\
\hline & $\mathbf{e}_{0}$ & $\mathbf{e}_{60}$ & $\mathbf{e}_{0}$ & $\mathbf{e}_{60}$ & $\mathrm{e}_{0}$ & $\mathbf{e}_{60}$ & $\mathrm{e}_{0}$ & $\mathbf{e}_{60}$ \\
\hline Warszawa & 75,2 & 20,3 & 81,7 & 24,2 & 73,6 & 19,4 & 81,5 & 24,1 \\
\hline Poznań & 74,5 & 19,5 & 81,0 & 23,6 & 73,7 & 18,6 & 80,7 & 23,2 \\
\hline
\end{tabular}

* Określenie „obszar podmiejski” jest stosunkowo mało precyzyjne, gdyż zamieszczone w tabeli dane dotyczą obszaru podregionu poznańskiego i warszawskiego (poziom jednostek NTS3 systemu TERYT).

Źródło: Baza Demografia, GUS, http://demografia.stat.gov.pl/bazademografia/CustomSelectData. aspx?s=lud\&y=2011\&t=00/30/64 (dostęp: 10.07.2014). 
Przeciętne trwanie życia jest silnie zróżnicowane terytorialnie. W 2002 r. nowo narodzony w mieście chłopiec mógł oczekiwać blisko 71 lat życia, podczas gdy urodzony na wsi równo 70 lat. W dużych miastach oczekiwane trwanie życia było nieco dłuższe, w Poznaniu wynosiło 72 lata, a w Warszawie - 74,7 roku. Relacja między przeciętnym trwaniem życia dziewczynek urodzonych w mieście i na wsi była dokładnie odwrotna $(78,6-79,1)$. Jednak warszawianki mogły oczekiwać 81 lat życia, gdy w przypadku poznanianek było ono krótsze niż dla mieszkanek wsi i wynosiło 78,7.

W 2013 r. następuje zrównanie trwania życia kobiet mieszkających w mieście i na wsi $(81,1)$. Dziewczynki urodzone w Warszawie nadal moga oczekiwać nieco dłuższego życia $(81,7)$ niż przeciętnie mieszkanki miast. Nie jest to prawdą w przypadku poznanianek $(81,0)$. W przypadku chłopców utrzymuje się relacja między przeciętnym trwaniem życia w mieście $(73,5)$ i na wsi $(72,4)$. Również nieco dłuższe jest także przeciętne trwanie życia w dużych miastach, w Warszawie $(75,2)$ i w Poznaniu $(74,5)$.

Dane statystyczne nie umożliwiają niestety porównań relacji między trwaniem życia w mieście oraz w jego bezpośrednim otoczeniu - obszarze podmiejskim. Informacje zamieszczone w tabeli 5 dotyczą podregionów ${ }^{27}$ obejmujących obszar większy aniżeli funkcjonalna strefa miejska. $\mathrm{Z}$ tego powodu poniższe uwagi należy traktować z należytą ostrożnością. Warto jednak zauważyć tendencje prowadzące do wyrównania oczekiwanego trwania życia. Wzrost trwania życia mężczyzn w latach 2002-2013 był wyraźnie większy w podregionie poznańskim (3,2 roku) aniżeli w mieście Poznaniu $(2,5)$. Na uwagę zasługuje tutaj szczególne wydłużenie oczekiwanego dalszego trwania życia mężczyzn w wieku 60 lat $\left(\mathrm{e}_{60}\right)$, które w podregionie poznańskim wyniosło 1,9 roku, a w mieście Poznaniu 1,7. Dla kobiet wielkości te sa jeszcze wyższe (2,3 - Poznań i 2,2podregion poznański). Obserwowana odwrotna relacja między zmianami dla miasta i podregionu potwierdza również wskazaną konwergencję. Podobne tendencje zaobserwować można także dla innych dużych miast. W Warszawie ich intensywność była jeszcze większa, na co wskazuje bardzo wysoki przyrost trwania życia dla podregionu (4,4 dla mężczyzn, 3,5 - dla kobiet) i stosunkowo niski w mieście stołecznym (0,5 dla mężczyzn i 0,7 - dla kobiet).

\section{CHARAKTERYSTYKA DEMOGRAFICZNO-SPOŁECZNA MIESZKAŃCÓW AGLOMERACJI POZNAŃSKIEJ}

Zaawansowanie procesu suburbanizacji oceniać można z perspektywy zmiany stanu ludności aglomeracji według miejsca zamieszkania. Wyjaśniając fazy rozwoju, wskazać można także zmiany natężenia procesów demograficznych, umieralności i płodności, przedstawione we wcześniejszych rozważaniach. Szczególne znaczenie zwrócono na tendencje prowadzące do zmniejszania się rozbieżności. Upodobnianie się zachowań demograficznych uwarunkowane

${ }^{27}$ Jest to podregion warszawski i poznański (NTS3 według klasyfikacji jednostek terytorialnych systemu TERYT). 
jest wieloma czynnikami o charakterze społecznym. Omówienie determinant płodności czy umieralności wykracza poza zakres tego opracowania, jednakże istotne wydaje się nawiązanie do dwóch zasadniczych kwestii, a mianowicie poziomu wykształcenia oraz sytuacji na rynku pracy, które w sposób symptomatyczny ujmuja zmiany demograficzne, społeczne i światopoglądowe oraz warunki życia. Poziom wykształcenia jest jednym z podstawowych czynników różnicujących kształtowanie się procesów demograficznych ${ }^{28}$. Zazwyczaj wyższy poziom wykształcenia wiąże się ze wzrostem oczekiwanego trwania życia oraz niższą płodnościa, co istotnie kształtuje strukturę wieku ludności. Wyższy poziom wykształcenia istotnie kształtuje także potrzebę aktywności, aspiracje zawodowe, rozwój przedsiębiorczości ${ }^{29}$. Korzystny efekt zmian związanych ze wzrostem wykształcenia, większym natężeniem aktywności ekonomicznej, ciągłym procesem uczenia się, podnoszenia i zmiany kwalifikacji, określany jest mianem „demograficznej dywidendy”. Zmiany wykształcenia, wydłużanie "trwania życia w dobrym zdrowiu” i związanego z tym czasu aktywności zawodowej moga potencjalnie kompensować skutki kurczenia się „młodych” roczników ludności w wieku produkcyjnym. Na podstawie przeprowadzonych analiz empirycznych J. C. Crespo et al. ${ }^{30}$ stwierdzaja, że wzrost poziomu wykształcenia siły roboczej wywiera stały, pozytywny i istotny wpływ na wzrost produktywności siły roboczej, na wzrost gospodarczy.

Polska jest państwem, w którym dynamika zmian w zakresie edukacji i poziomu wykształcenia jest wyjątkowo wysoka. W $1991 \mathrm{r}$. studiowało w Polsce 404 tys. studentów, w $2011 \mathrm{r} .{ }^{31}$ było ich ponad 1841 tys. Liczba studentów wzrosła 4,6 razy. Zaznaczyć jednak należy, że wskutek niżu demograficznego od 2007 r. liczba studentów maleje. Masowość dotyczy już nie średniego, lecz także wyższego poziomu wykształcenia, zarówno licencjatu, jak i poziomu magisterskiego. Motywacje w zakresie potrzeby kształcenia są oczywiście różne. Wśród zmian okresu transformacji można jednak podkreślić m.in. trudną sytuację na rynku pracy, chęć zdobycia lepszych, wyższych kwalifikacji, sprostania konkurencji, awansu zawodowego i społecznego, wreszcie otwarcie europejskiego rynku pracy po akcesji do Unii Europejskiej.

W efekcie tylko w dekadzie między spisami powszechnymi 2002 i 2011 r., odsetek ludności posiadającej wyższe wykształcenie w Polsce zwiększył się z $9,9 \%$ do $17 \%$ (por. tab. 6). Jest on oczywiście bardzo zróżnicowany według wieku, ale także według płci ${ }^{32}$ i miejsca zamieszkania. W Poznaniu odsetek osób z wyższym wykształceniem zwiększył się z 17\% w 2002 r. do 31\%

${ }^{28}$ Por. W. Lutz et al., op. cit.; W. Lutz, A Population Policy Rationale for the Twenty - First Century, „Population and Development Review” 40, 2014, nr 3 (September), s. 527-544.

${ }^{29}$ Por. J. C. Crespo, W. Lutz, W. Sanderson, Is the Demographic Dividend an Education Dividend?, „Demography” 51, 2014, s. 299-315, DOI 10.1007/s13524-013-0245-x; I. E. Kotowska (red.), op. cit.; I. Grabowska, Developments of Employment by Broad Age-groups in Poland in the Years 1998-2008. Do Their Determinants Differ?, „Studia Demograficzne” 2014, nr 1(165), s. 55-82.

${ }^{30}$ J. C. Crespo, W. Lutz, W. Sanderson, op. cit.

${ }^{31}$ Porównania z 2011 r. przeprowadzono dlatego, że informacje o poziomie wykształcenia dostępne są na podstawie spisów ludności.

${ }^{32}$ Według danych NSP 2011 w Polsce kobiety stanowią ponad 58\% ludności posiadającej wyższe wykształcenie. 
w 2011 r. Wśród mieszkańców miasta w wieku 25-29 lat wyższe wykształcenie ma blisko $60 \%$. W Warszawie najwyższy odsetek osób z wyższym wykształceniem dotyczy kolejnej grupy wieku (30-34 lata) i wynosi 63\%. Począwszy od tych „dominujących” grup, wraz z wiekiem udział osób z wyższym wykształceniem maleje, choć i tak jest wyraźnie wyższy niż średni poziom w kraju.

Tabela 6

Odsetek ludności posiadającej wyższe wykształcenie,

mieszkańcy aglomeracji Poznania i Warszawy na tle kraju w latach 2002-2011

\begin{tabular}{|c|c|c|c|c|c|c|c|c|}
\hline \multirow[b]{2}{*}{ Wiek } & \multicolumn{4}{|c|}{ Aglomeracja warszawska } & \multicolumn{4}{|c|}{ Aglomeracja poznańska } \\
\hline & 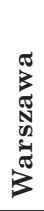 & 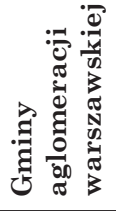 & 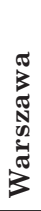 & 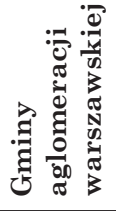 & 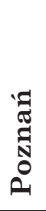 & 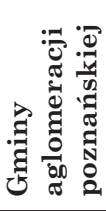 & 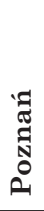 & 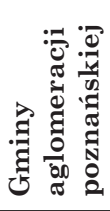 \\
\hline \multirow{2}{*}{ Ogółem } & \multicolumn{2}{|c|}{2002} & \multicolumn{2}{|c|}{2011} & \multicolumn{2}{|c|}{2002} & \multicolumn{2}{|c|}{2011} \\
\hline & 21 & 11 & 38 & 21 & 17 & 5 & 30 & 23 \\
\hline $20-24$ & 10 & 8 & 23 & 16 & 9 & 2 & 22 & 15 \\
\hline $25-29$ & 40 & 22 & 61 & 42 & 37 & 9 & 57 & 40 \\
\hline $30-34$ & 36 & 19 & 63 & 41 & 30 & 10 & 52 & 42 \\
\hline 35-39 & 30 & 15 & 56 & 33 & 26 & 8 & 43 & 38 \\
\hline $40-44$ & 26 & 13 & 46 & 25 & 23 & 7 & 34 & 28 \\
\hline $45-49$ & 26 & 11 & 37 & 20 & 24 & 6 & 28 & 20 \\
\hline $50-54$ & 26 & 11 & 32 & 16 & 23 & 5 & 26 & 18 \\
\hline $55-59$ & 28 & 11 & 30 & 13 & 22 & 4 & 25 & 15 \\
\hline $60-64$ & 26 & 10 & 30 & 13 & 21 & 3 & 23 & 15 \\
\hline 65 i więcej & 21 & 5 & 28 & 9 & 16 & 2 & 20 & 10 \\
\hline
\end{tabular}

Źródło: Bank Danych Lokalnych, GUS.

Jest naturalne, że Poznań jako ośrodek akademicki, centrum naukowe i kulturalne regionu skupia osoby z wyższym wykształceniem. Jednak również wśród mieszkańców obszaru podmiejskiego nastapiły istotne zmiany w zakresie poziomu wykształcenia (por. wykres 5 i 6). Jeśli odsetek poznanian z wyższym wykształceniem wzrósł prawie dwukrotnie $(1,8)$, to wśród mieszkańców obszarów podmiejskich wzrost ten był ponad dwukrotny $(2,13)$. Dynamika zmian zachodzących $\mathrm{w}$ obszarze podmiejskim przewyższa tempo przyrostu liczby osób z wyższym wykształceniem w centrum miasta. Jest to efekt modyfikacji charakteru obszarów bezpośredniego sasiedztwa miasta, zmian w zakresie stylu życia, spotęgowany przez proces suburbanizacji. 


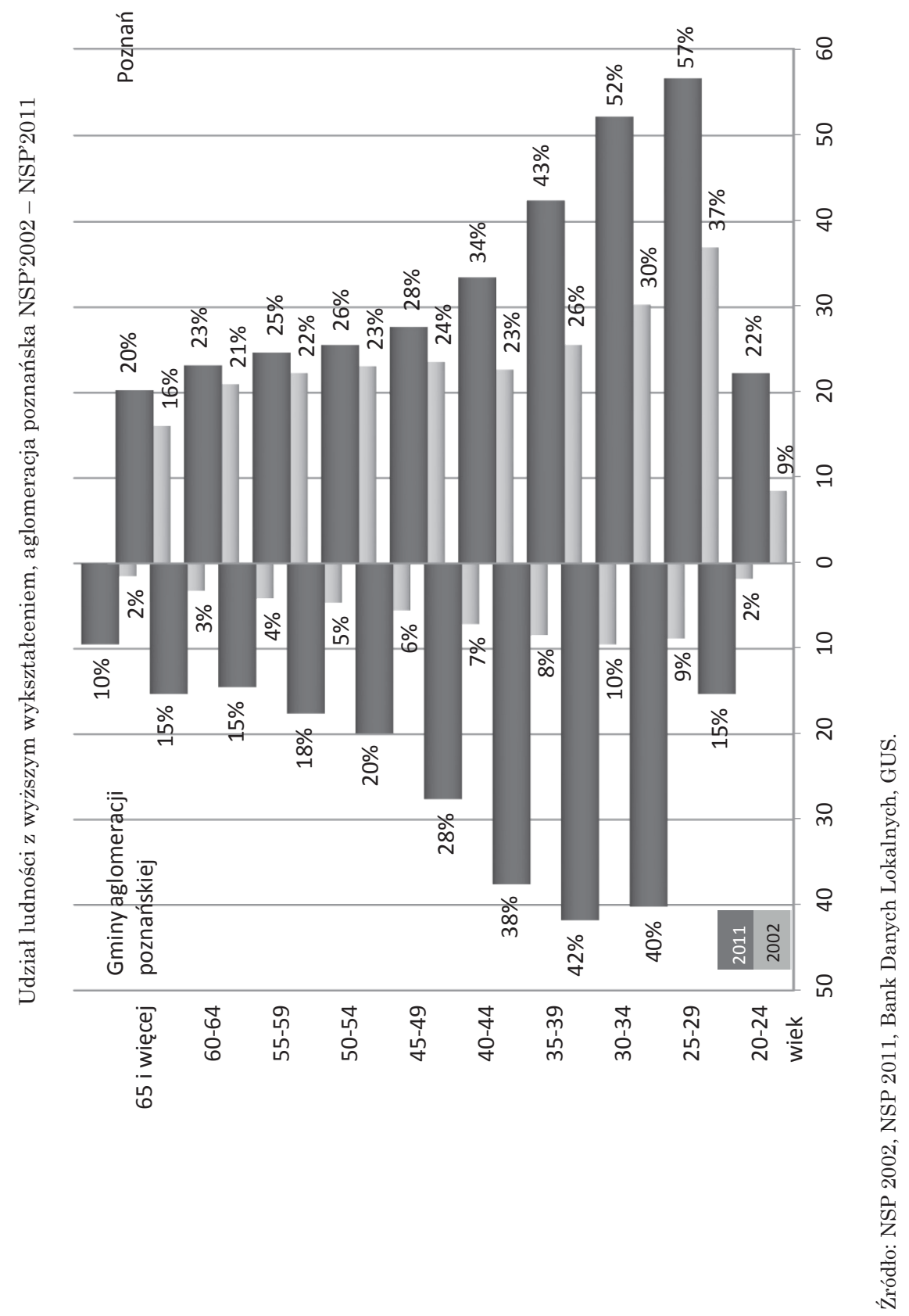




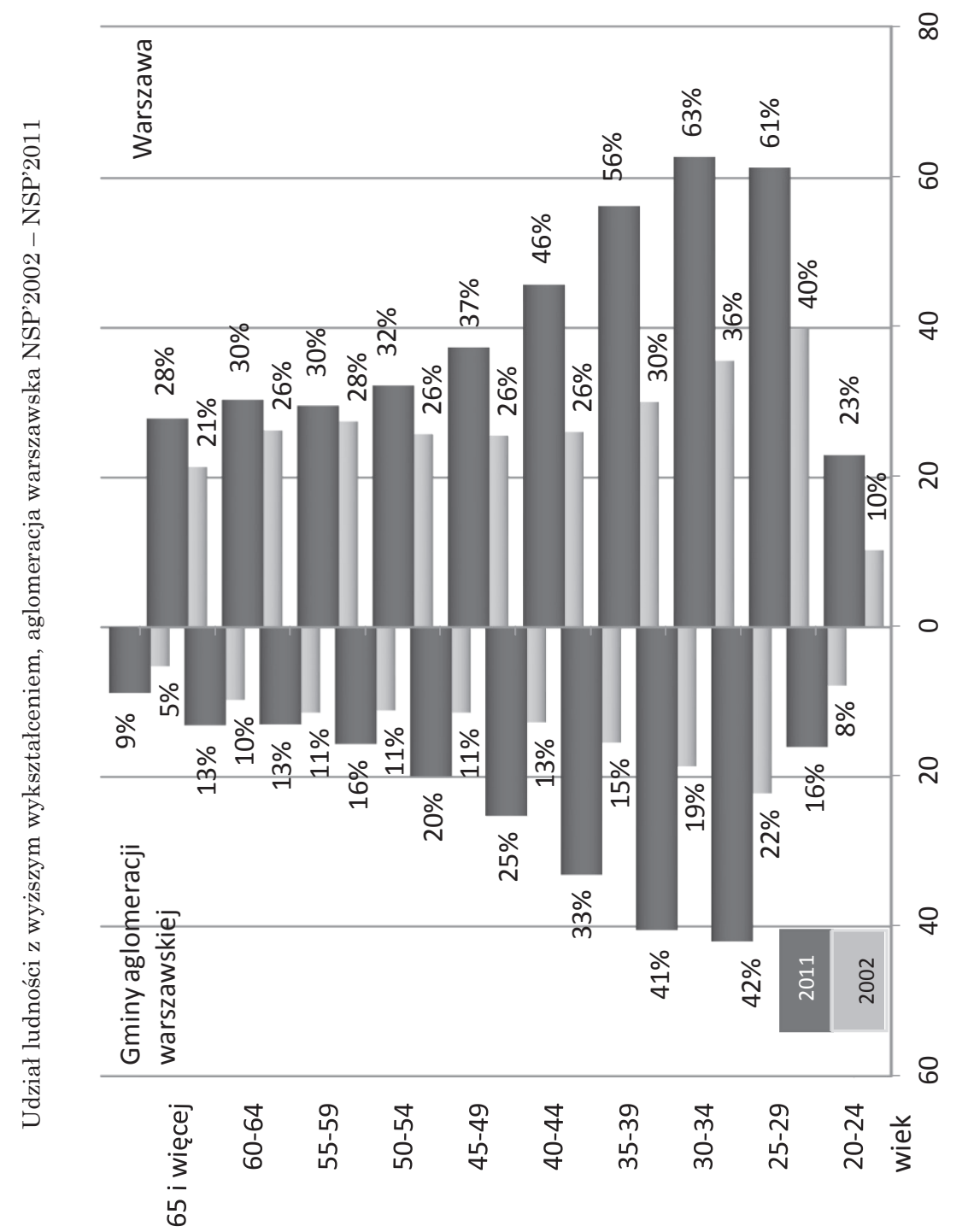

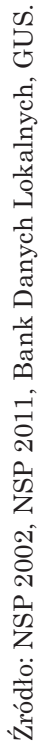


Cechą charakterystyczna rynku pracy w Polsce jest silne zróżnicowanie terytorialne. Stwierdzenie to dotyczy zarówno rodzaju aktywności ekonomicznej, jej natężenia, jak i poziomu stopy bezrobocia. W końcu IV kwartału 2013 r. stopa bezrobocia w miastach i na wsi kształtowała się na zbliżonym poziomie $^{33}$. W największych miastach, liczących powyżej 500 tys. mieszkańców, stopa bezrobocia była niższa $(6,7 \%)$ niż w dużych miastach (100 000 499 999), gdzie wynosiła 9,7\%. Jeszcze wyższy jest poziom bezrobocia w miastach średnich i małych - 11,5\%. Również w bezpośrednim sąsiedztwie dużych miast bezrobocie jest wyższe (por. tab. 7).

Rynek pracy w Poznaniu i najbliższej okolicy charakteryzuje jeden z najniższych w kraju poziom bezrobocia. Dodatkowo różnica w wartościach statystyk dla miasta oraz jego najbliższego otoczenia jest bardzo niewielka. W końcu 2013 r. odsetek bezrobotnych, którzy spełniali warunki określone w ustawie o promocji zatrudnienia i instytucjach rynku pracy ${ }^{34}$, w powiecie grodzkim Poznań wynosił $4,1 \%$. W powiecie poznańskim odsetek ten był o pół punktu procentowego wyższy i wynosił $4,6 \%$ (por. tab. 7 ).

Tabela 7

Stopa bezrobocia rejestrowanego w aglomeracji Poznania i Warszawy na tle kraju w latach 2002-2013

\begin{tabular}{|c|c|c|c|c|c|c|c|c|c|c|}
\hline \multirow[b]{3}{*}{ Wiek } & \multicolumn{10}{|c|}{ Stopa bezrobocia rejestrowanego } \\
\hline & \multirow{2}{*}{$\begin{array}{l}2002 \\
\\
\frac{\pi}{\pi} \\
\frac{\pi}{0} \\
2\end{array}$} & \multicolumn{2}{|c|}{$\begin{array}{l}\text { Centrum } \\
\text { miasta }\end{array}$} & \multicolumn{2}{|c|}{$\begin{array}{c}\text { Obszar } \\
\text { podmiejski }\end{array}$} & \multirow{2}{*}{$\begin{array}{l}2013 \\
\\
\frac{\pi}{\square} \\
\frac{\pi}{0} \\
2\end{array}$} & \multicolumn{2}{|c|}{$\begin{array}{l}\text { Centrum } \\
\text { miasta }\end{array}$} & \multicolumn{2}{|c|}{$\begin{array}{c}\text { Obszar } \\
\text { podmiejski }\end{array}$} \\
\hline & & 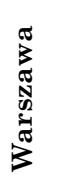 & 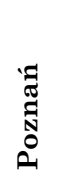 & 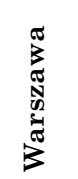 & 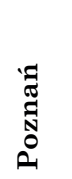 & & 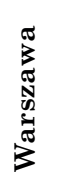 & 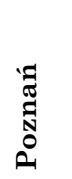 & 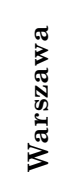 & 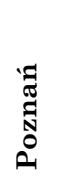 \\
\hline Ogółem & 20,0 & 6,2 & 6,7 & 15,7 & 9,7 & 13,4 & 4,8 & 4,1 & 11,3 & 4,6 \\
\hline
\end{tabular}

Źródło: GUS, Bezrobocie rejestrowane, I-IV kwartat 2002, Warszawa 2003; GUS, Bezrobocie rejestrowane, I-IV kwartat 2013, Warszawa 2014.

W innych dużych miastach poziom bezrobocia jest również niski, ale różnice obserwowane dla miasta oraz obszarów podmiejskich sa zdecydowanie większe, np. dla Warszawy wynoszą 5,5 punktu procentowego, a dla Krakowa 6,6 punktu procentowego.

Oceniając sytuację na rynku pracy przez pryzmat statystyki, jaką jest stopa bezrobocia rejestrowanego, trzeba jednak zauważyć mankamenty tej miary. Do najistotniejszych należy rozbieżność pomiaru liczby bezrobotnych 2014.

${ }^{33}$ Por. GUS, Aktywność ekonomiczna ludności Polski w IV kwartale 2013 roku, Warszawa

${ }^{34}$ Ustawa o promocji zatrudnienia i instytucjach rynku pracy z 14 marca 2014 r., Dz. U. 2014, poz. 598 . 
i liczby aktywnych zawodowo, tj. licznika i mianownika. Liczba bezrobotnych jest określona według miejsca zamieszkania, podczas gdy liczba aktywnych zawodowo mierzona jest według lokalizacji miejsca pracy ${ }^{35}$. Duża liczba osób dojeżdżajacych do pracy do miasta - centrum regionu powoduje oczywiste zawyżenie mianownika oraz niedoszacowanie stopy bezrobocia. Rozbieżności mogą być bardzo znaczne.

\section{PODSUMOWANIE}

Przedmiotem badania była charakterystyka rozwoju demograficznego Poznania. Omówiono proces starzenia się ludności aglomeracji miasta z uwzględnieniem relacji centrum - obszar podmiejski. Przedstawione wyniki badań wskazuja na postępujący proces suburbanizacji. Jednakże obserwowane w ostatnich latach obniżenie przeciętnego rocznego wzrostu liczby ludności powiatu poznańskiego przy jednoczesnym coraz słabszym spadku liczby mieszkańców Poznania sugerują fazę absolutnej dezurbanizacji w rozwoju miasta. Trudno jednoznacznie określić wpływ nieco większego wzrostu dzietności poznanianek na tle otaczającego regionu. Z kolei zmiany trwania życia wskazuja na upodobnianie się charakterystyk procesów demograficznych w mieście oraz jego najbliższym otoczeniu. Wśród przyczyn konwergencji wskazano więc intensywniejsze wydłużanie trwania życia oraz wyraźniejsze obniżenie płodności wśród mieszkańców strefy podmiejskiej. Podkreślono jednak nadal utrzymujące się wyraźnie wyższą płodność w powiecie poznańskim oraz zaawansowanie procesu starzenia.

Analiza relacji między zmianami procesów demograficznych i charakterystyk społecznych pozwoliła podkreślić wyjątkowo wysoka dynamikę zmian zachodzacych w obszarze podmiejskim. Tempo przyrostu osób z wyższym wykształceniem w najbliższym otoczeniu Poznania znacznie przewyższa obserwowane w centrum miasta. Wskazano wpływ wzrostu wykształcenia na rozwój kariery zawodowej, ustawiczne kształcenie, wydłużanie okresu aktywności, a także na decyzje matrymonialne, prokreacyjne, częstsze i szybsze powroty do pracy po urodzeniu dziecka. Wzrost poziomu wykształcenia siły roboczej wywiera stały, pozytywny i istotny wpływ na wzrost gospodarczy.

Suburbanizację w decydującej mierze można uznać za przyczynę zmniejszania się liczby ludności Poznania. Warto jednak podkreślić, że zmiany obserwowane w strukturze ludności według miejsca zamieszkania, w podziale na miasto i wieś, wymagają odpowiedniej interpretacji. Z jednej strony obszary podmiejskie posiadające status wsi zdecydowanie zmieniaja swój charakter. Sa to raczej osiedla domków jednorodzinnych czy szeregowych, często posiadajace własne centra handlowo-usługowe, $\mathrm{z}$ dużym udziałem terenów zielonych. Mieszkańcy tych osiedli nie są związani z rolnictwem, często dojeżdżają do pracy, szkoły, kina i teatru do miasta - centrum regionu. Z dru-

35 Dodatkowo pojawić się może jeszcze rozbieżność między miejscem pracy w sensie siedziby firmy a rzeczywistym miejscem wykonywania pracy. 
giej strony tradycyjna wieś, której mieszkańcy trudnią się przede wszystkim rolnictwem, jest również inna. Rozwój nowoczesnych technologii, w tym powszechny dostęp do Internetu, oraz postęp w zakresie rozwoju infrastruktury powoduja zmniejszanie się dystansu między miastem i wsią. Zwiększanie się liczby ludności mieszkającej na wsi zdaje się wymagać zmiany tradycyjnego sposobu postrzegania procesu urbanizacji oraz związanych z nim charakterystyk stylu życia.

dr hab. Elżbieta Gołata

Profesor Uniwersytetu Ekonomicznego w Poznaniu

elzbieta.golata@ue.poznan.pl

\title{
DEMOGRAPHIC GROWTH OF THE CITY OF POZNAŃ
}

\author{
Sum mary
}

The aim of this paper is to present the past and the future trends in the development of the population of the city of Poznań. The purpose of the research is also to indicate the links and relationships between the demographic development of the city and the surrounding suburban areas in relation to the ageing of the population, the labour market and levels of education.

The reduction of the average annual population growth in fringe, or suburban areas, accompanied by a decline in the number of inhabitants of Poznań city suggests an absolute phase of de-urbanisation of the city. While the impact of a slightly higher than in the fringe areas increase in fertility of Poznań female residents is hard to determine, both areas show increasingly similar characteristics in the changes in life expectancy.

The demographic processes are analysed in association with social changes. The growth-rate of university graduates in the Poznań area (fringe) is much higher than that observed in the city centre. The impact of education on career, extension of the period of economic activity, as well as on decisions about marriage and fertility is discussed. The increase in the educational level of the labour force has a constant, positive and significant impact on economic growth. 
